\title{
Study on the Performance of Irreversible Solid Oxide Fuel Cell- Heat Engine Hybrid Power System
}

\author{
Liwei Chen ${ }^{1,2, *}$, Yingyan Lin ${ }^{1}$ \\ ${ }^{1}$ School of Mechanical \& Electronic Engineering, Sanming University, Sanming 365004, China; \\ ${ }^{2}$ Department of Mechanical Engineering, University of South Carolina, Columbia, 29208, South \\ Carolina, USA. \\ *E-mail: 125601497@qq.com
}

doi: $10.20964 / 2021.05 .43$

Received: 3 January 2021 / Accepted: 8 March 2021 / Published: 31 March 2021

\begin{abstract}
An irreversible solid oxide fuel cell by the hybrid of Stirling heat engine system is built, whose irreversibility in the process of system are considered, such as solid oxide fuel cell irreversible losses, the irreversible loss of the Stirling heat engine working process, and heat conduction between them. Analytical expressions of the key processes are given by electrochemical analysis. Through numerical simulation, various factors affecting the performance of the hybrid system are discussed in detail, and the optimal working range of the hybrid system is deduced. This research shows that the efficiency of the hybrid power system can reach nearly $90 \%$ under all the ideal conditions.
\end{abstract}

Keywords: irreversible solid oxide fuel cell, hybrid power system, performance, optimal working range

\section{FULL TEXT}

(C) 2021 The Authors. Published by ESG (www.electrochemsci.org). This article is an open access article distributed under the terms and conditions of the Creative Commons Attribution license (http://creativecommons.org/licenses/by/4.0/). 